\title{
Ceramic supplier selection using analytical hierarchy process method
}

\author{
Filda Rahmiatia ${ }^{*}$, Syafei, M. Yani ${ }^{b}$, Purwanto ${ }^{a}$, Jonathan Andianto ${ }^{a}$ \\ aDepartment of Management, President University, Cikarang, Indonesia \\ bDepartment of Industrial Engineering, President University, Cikarang, Indonesia \\ filda.rahmiati@president.ac.id; yanisyafei@president.ac.id; purwanto@president.ac.id; \\ jonathan.andianto14@gmail.com
}

*Corresponding Author: filda.rahmiati@president.ac.id

\section{ARTICLE INFO}

\section{Keywords}

Analytical Hierarchy

Process;

Ceramics;

Supply chain;

Supplier Selection.

\section{Article history}

Received:

July 8, 2021

Revised:

July 27, 2021

Accepted:

August 17, 2021

Published online:

August 31, 2021

\section{ABSTRACT}

This study tried to implement the Analytical Hierarchy Process (AHP) and the weights of the criteria and sub-criteria to find the best supplier. According to QCDFR (quality, cost, delivery, flexibility, and responsiveness). This study took place in one of the biggest tile producers, ranks fifth in the world and the first in Indonesia. However, the company currently only uses quality, cost, and delivery methods to choose the best supplier of raw material, namely feldspar. This research tries to use the systematic method to find the best supplier based on the importance of the criteria. The method used the quantitative approach to enumerate the data to analyze the information. The company analyzed six suppliers. The primary tool used in this research is a Super Decision Software version 3.2 to create and manage the AHP model, enter the judgments, get results, and perform sensitivity analysis on the results. The result found that Semarang is the best supplier. The company will choose Semarang to become the company's business partner compared to the other suppliers because Semarang has met the criteria that the company prioritizes the most. By having the best supplier selection, the company can provide the right material consistency and suitable material suitability.

\section{Introduction}

Supplier selection is part of the supply chain management domain, and we believed having a competitive supply chain is critical in the competitive industry. Generally, selecting the best supplier is one of the essential decisions that determine the company's existence and good functioning (Galińska \& Bielecki, 2017). Supplier selection must be appropriately made because the wrong supplier selection will result in various negative consequences and losses for the company (Salimi \& Edalatpnanah, 2020), such as can disrupt the production process and company performance. Suppliers play an essential role in the availability of raw materials for a company's ongoing production activity; thus, the companies need to cooperate with the best supplier to support their business performance (Rohimat, 2018). Added, selecting the best 
supplier can help the company achieve the desired production results, leading to increased company's business performance (Pirogo \& Rumita, 2017). More importantly, a selecting supplier has a more significant impact on business performance, in which the supplier selection must be taken into consideration (Navasiri et al., 2016).

Companies need to consider several criteria to select the supplier (Rohimat, 2018). The most common supplier selection criteria were quality, cost, and delivery (Cengiz et al., 2017). Several studies have shown that quality is an essential criterion for managers (Navasiri et al., 2016). In a practical approach, cost and delivery become crucial criteria for managers when decisions are made (Kusaeri et al., 2016; Putra et al., 2020). Therefore, supplier selection becomes a complex problem in the company as the decision must be made carefully to select the best supplier (Navasiri et al., 2016). Supplier selection is a rather tricky thing because not all suppliers can meet all the company's criteria. Suppliers that provide raw material at a lower cost still cannot guarantee the quality that they provide (Rohimat, 2018).

QCDFR (quality, cost, delivery, flexibility, and responsiveness) model is developed by (Li et al., 1997 ) and has been cited by many studies. This model is associated with using the Analytical Hierarchy Process (AHP) because it is the systematic method to find the best supplier based on the importance of the criteria (Winarso et al., 2021; Yuliani et al., 2017). Therefore, a broad single model approach like AHP has been proposed for supplier selection (Alvira \& Rusdah, 2020; Susilo \& Mahdiana, 2020) because the method is mainly used as a decision tool to decide in a multicriteria decision-making situation (Dinna, 2019).

This study found that the ceramic company's supplier selection is only judged based on quality, cost, and delivery. The company has few indicators to select the supplier while there are six suppliers to supply the feldspar. Moreover, it is found that the company also does not have a systematic method to find the best supplier when several criteria must be considered and used in the company. Some similar studies have been conducted in the case of supplier selection by using the AHP method with the five criteria based on the QCDFR model (Pramita \& Wirawan, 2019; Wardhana \& Prastawa, 2018; Yuliani et al., 2017).

All those studies used the AHP method by structuring the hierarchical elements, such as goal, criteria, sub-criteria, and alternatives. However, none of the prior studies have more than five suppliers as their alternatives. Therefore, this study is motivated to run the survey more comprehensively by having more suppliers as the company's alternatives to meet the company's goal, which is to select the best supplier. Although all prior studies have conducted a similar topic, this research is different as the type of business in this research is more focused on a tile manufacturing company as one of the biggest tile ceramic tile producers in the world and Indonesia. Therefore, the AHP method is needed to help the company select which supplier is the best by evaluating the most important criteria required by the company.

\section{Literature Review}

\subsection{Supply Chain}

The supply chain has been recognized as a key factor of companies' success and particularly one of the best means by which companies can achieve a goal of paramount importance: enhance customer satisfaction. That is why systems to measure and manage supply chain performance are becoming fundamental (Siham et al., 2015). A supply chain is an integrated manufacturing process in which the supplier supplies raw materials to the manufacturer, and raw materials are 
manufactured into final products. The finished goods are sent to the dealer, a retailer and finally delivered to customers (Goli \& Davoodi, 2018).

To survive in today's business, many manufacturing companies need to determine the best supplier who can supply excellent quality raw material, notably to support companies in producing quality products (Sinaga \& Siregar, 2017). A supplier is a party who provides a resource in the form of raw materials needed by companies (Viarani \& Zadry, 2015). Therefore, the supplier is one of the external parties essential for a manufacturing company's existence and sustainability (Didi, 2016; Sinaga \& Siregar, 2017).

\subsection{QCDFR Model}

QCDFR model consists of five criteria: quality, cost, delivery, flexibility, and responsiveness, which were recently studied by Alvira \& Rusdah (2020) and Susilo \& Mahdiana (2020). The following five criteria are as follow:

1. Quality. This criterion assesses suppliers in terms of the quality of raw material supplied by the supplier.

2. Cost. This criterion is a financial criterion in which raw material cost is the primary consideration of each factor in selecting suppliers.

3. Delivery. This criterion assesses suppliers in terms of on-time delivery and the accuracy of quantity sent by suppliers.

4. Flexibility. This criterion assesses suppliers' ability to adapt to the unpredictable quantity change and order time change.

5. Responsiveness. This criterion assesses suppliers in terms of the ability of suppliers to respond to problems and urgent orders.

\subsection{Analytic Hierarchy Process (AHP)}

AHP is a method developed to simplify decision-making by structuring hierarchical elements, such as goals, criteria, sub-criteria, and alternatives. Generally, AHP is the most popular or primary method to combine people's judgment and data to virtually rank options and predict the results (Pirogo \& Rumita, 2017). AHP is used to set priorities from various alternatives or options when multiple criteria must be used (Akmaludin \& Suryanto, 2016; Haryanto \& Sadeyah, 2018). This method will allow the decision-maker to structure the most complicated problem at a hierarchical level. Moreover, AHP can be considered a tool to translate qualitative and quantitative evaluations made by the experts into multi-criteria ranking (Yuliani et al., 2017).

AHP is widely used to set priorities from various alternatives or options, and the choices are complex or multi-criteria (Akmaludin \& Suryanto, 2016).
a. Decomposition
After the problem is defined, decomposition is processed. Decomposition separates the complete problem into the smallest elements: goal, criteria, sub-criteria, and alternatives.
b. Priority Determination
AHP conducts element priority analysis using the pairwise comparison method. This priority is determined based on the opinions of experts through interviews and questionnaires.
c. Comparative Judgement 
Comparative judgment creates the appraisal of relative importance between two elements. This assessment will be presented in the pairwise comparison matrix, which means that every element will be compared in a pair.

d. Calculate the geometric mean

After obtaining the pairwise comparison questionnaire result, the geometric mean must be calculated if the respondent is more than one. The purpose of the geometric mean is to look for the averages for categorical data answers.

e. Logical Consistency

AHP measures the consistency thoroughly from some considerations through the consistency ratio. A consistency ratio is needed to check the consistency of the data. If the value of $C R$ is more than 0.1 or $10 \%$, then it must be corrected. It means that the result of $\mathrm{CR}$ can be said correctly if the value is less than 0.1 or $10 \%$.

\section{Research Method}

In this research, the researchers decided to use a descriptive method with a quantitative approach. A descriptive method is a method that aims to make a systematic, factual, and accurate description or facts about the phenomenon under investigation (Sugiyono, 2017). This research used the quantitative approach to enumerate the data to analyze the information.

\subsection{Research Instrument}

Primary data is the main data collection optimized in this research, as it is considered the most suitable approach. Primary data is a source of research data obtained directly from sources and can be obtained from opinions and observation (Sugiyono, 2017). The research framework is shown in Figure 1.

The investigation begins with an examination of the problem in raw materials sent by the supplier, followed by the distribution of a pairwise comparison questionnaire to experts from three departments, namely the Purchasing Department, the Material Department, and the Quality Control Department, followed by an interview with the Quality Control Manager. Respondents or experts rate the importance of the criteria, sub-criteria, and suppliers in these pairwise comparison questionnaires. The grading scale is evaluated using the AHP judgment scale. The information will be organized into a matrix. Following the collection of results from pairwise comparison questionnaires and their development into a matrix, the geometric mean must be calculated as the decision is made by three experts. Furthermore, the geometric mean for criteria is calculated using Microsoft Excel 2013. Following the discovery of all geometric mean results, the consistency ratio of each criterion and sub-criterion was calculated using Super Decision Software. Next, enter each supplier's geometric mean results for each sub-criteria into Super Decision Software. As a result, the supplier's consistency ratio. This step will define the supplier's rank after all of the consistency ratio results have been obtained using Super Decision Software.

The primary analysis tool that will be used in this research is Super Decision Software version 3.2. Super Decision is a decision-making software designed to create and manage the AHP model, enter the judgments, get results, and perform sensitivity analysis on the results. The researcher also maximized Microsoft Excel 2013 in transforming the raw data from questionnaires to find the Geometric Mean, which is to look for the averages for categorical data answers.

\subsection{Data Collection Method}


All information related to supplier selection is gathered. The data is collected by (Sugiyono, 2017):

1. Observation

Observation is a technique of collecting the data and information from primary data by optimizing researchers' observations. The researcher conducted the observation to identify the current policy for supplier selection in the company.
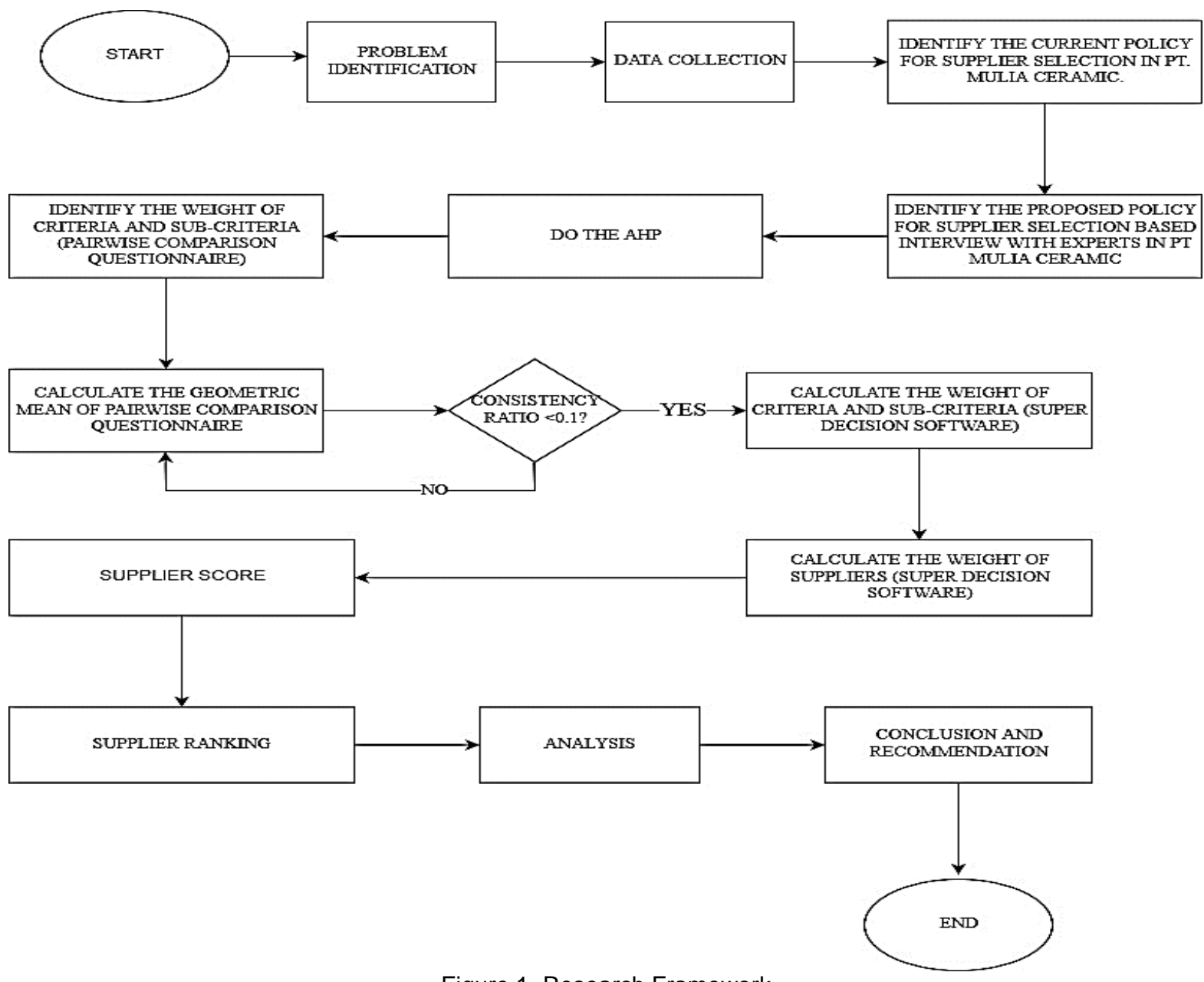

Figure 1. Research Framework

2. Interview

The interview method collects data if researchers want to conduct a preliminary study to find problems that must be studied. The researcher was interviewed to determine the proposed policy for supplier selection in the company.

3. Questionnaire

The questionnaire lists written questions formulated beforehand, which the respondent will answer, usually in clearly defined alternatives. The questionnaire used in this study is the pairwise comparison judged by the AHP judgment scale. The researcher spread the questionnaires to the experts in The Ceramic Company. This study's focus was more 
general, in which only the opinions matter, and there was no restriction for the age or status of the participants in this study.

\subsection{Data Analysis}

After collecting the data, the researchers decided to use the AHP method to prioritize and rank the alternatives in this study to reach its objectives. This research is helped with super decision software to find the weight of criteria and sub-criteria and rank which supplier is the best. The steps of analysis will be mentioned below, as follows:

1. Define the goal, criteria, sub-criteria, and alternatives.

Firstly, AHP needs to have the goal, criteria, sub-criteria, and alternatives (suppliers) to achieve its purpose of selecting the best supplier.

2. Perform the pairwise comparison

The pairwise comparison used to rank the importance level of every criterion, sub-criteria, and supplier can be expressed. Fill in the questionnaire using the score assessment following the AHP Judgement scale from 1 until 9. Then, the respondent questionnaire answers will be calculated in the shape of matrices.

3. Calculate the geometric mean

After obtaining the pairwise comparison questionnaire result from three respondents, the geometric mean is calculated by using Ms. Excel 2013 to get the mean.

4. Super Decision Software

In this part, all results of the geometric mean from Ms. Excel 2013 will be entered into Super Decision Software. Then, all the weight of criteria, sub-criteria, and suppliers can be defined.

5. Final Score

In this step, the supplier's rank will be defined based on Super Decision Software.

6. Analysis

In this step, data collection will be analyzed and discussed to find the research result.

\section{Results}

The company, which is the object of research, is a manufacturing company that produced ceramic tiles. The company is one of the biggest manufacturing companies that produces ceramic tiles in Indonesia. To produce ceramic tiles, the company needs to cooperate with suppliers who can supply raw materials. The company has six suppliers that supply feldspars, such as Sejahtera Gemilang, Semarang Mineral Pembangunan, Valpak, Mahkota Alam Sejahtera, Dian Lestari Sejahtera, and Makmur Sejahtera Abadi.

This study uses the QCDFR (quality, cost, delivery, flexibility, and responsiveness) model in the ceramic company's supplier selection. In this study, the proposed policy for supplier selection is decided by conducting interviews with three experts in the company who are Purchasing Manager, Material Manager, and Quality Control Manager, shown in Table 1.

Table 1. The proposed policy for supplier selection

\begin{tabular}{|c|l|}
\hline Criteria & \multicolumn{1}{|c|}{ Sub-criteria } \\
\hline \multirow{2}{*}{ Quality } & 1. Material suitability with the required specification \\
\cline { 2 - 2 } & 2. Material consistency \\
\hline Cost & 1. Raw material cost \\
\hline
\end{tabular}




\begin{tabular}{|c|l|}
\hline Criteria & \multicolumn{1}{|c|}{ Sub-criteria } \\
\hline \multirow{2}{*}{ Delivery } & 2. Method of payment \\
\cline { 2 - 2 } & 3. Delivery cost \\
\cline { 2 - 2 } & 1. Accuracy of the quantity sent \\
\hline \multirow{2}{*}{ Flexibility } & 1. An-time delivery \\
\cline { 2 - 2 } & 2. Ability to adapt to the unpredictable quantity change \\
\hline \multirow{2}{*}{ Responsiveness } & 1. Quick response regarding the quality problem \\
\cline { 2 - 2 } & 2. Quick response regarding urgent order \\
\hline
\end{tabular}

After obtaining the criteria and sub-criteria based on the QCDFR model, decomposition will be processed. The process of this analysis is called the hierarchy. This study's hierarchical structure consists of goals, criteria, sub-criteria, and alternatives, as shown in Figure 2.

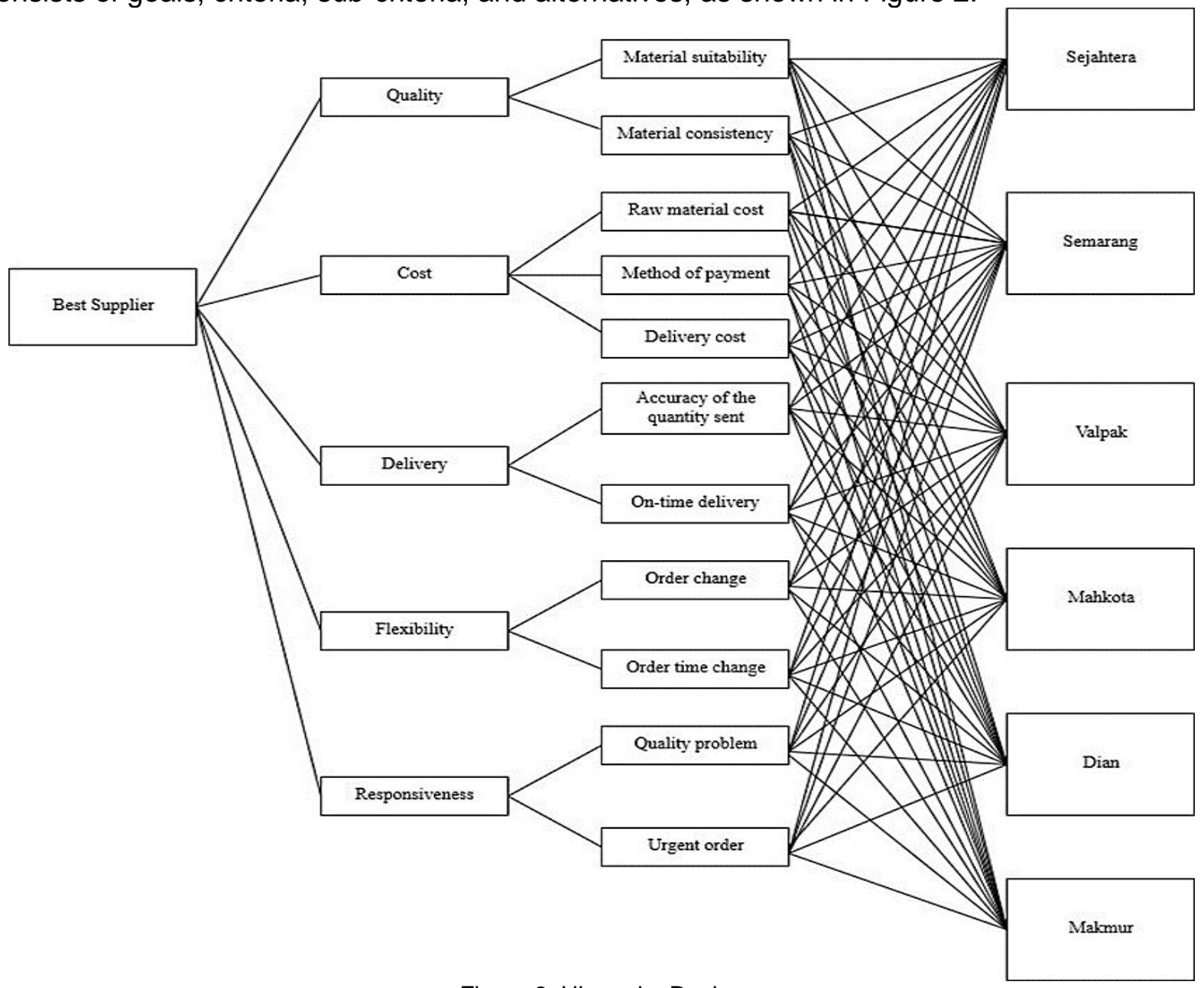

Figure 2. Hierarchy Design

\subsection{Data Processing Results}

The weights of the criteria were obtained with the help of Super Decision Software, as shown in Figure 3. The criteria with the highest priority weight value will be the most important in terms 
of supplier selection. Figure 3 showed that the criteria of quality occupy the top priority with a total score of 0.456 . As criteria of quality occupy the top priority, therefore this result is following the study by Pramita \& Wirawan (2019), Wardhana \& Prastawa (2018), and Yuliani et al. (2017) resulted that quality occupies the top priority in selecting the supplier. Thus, with this weight value, the company will automatically look for the supplier with the right quality than the supplier with good flexibility. As mentioned in the literature study, raw material quality must be controlled to produce quality products. Therefore, quality criteria in selecting a supplier are needed.

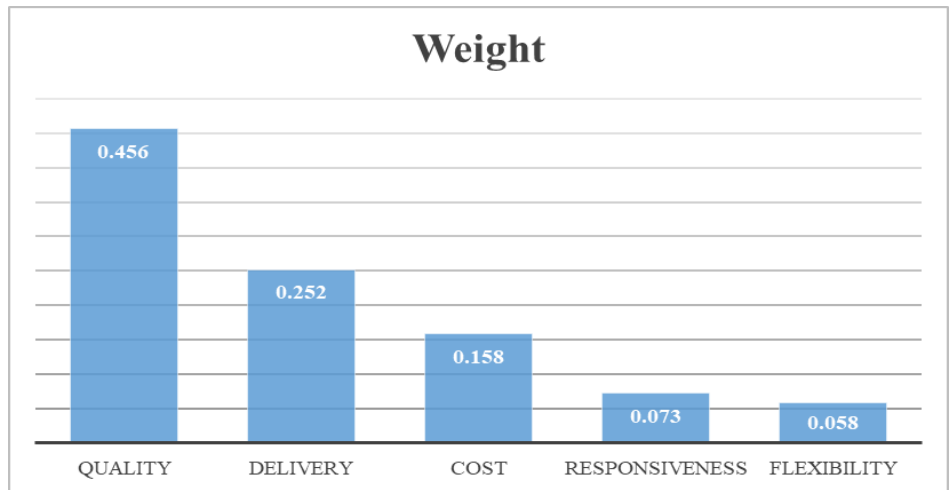

Figure 3. Summary of the weight of the criteria

After obtaining the weight of the criteria, knowing the weight of the sub-criteria is also needed to get appropriate and proportional options so that the company's objectivity is more certain to select the best supplier accurately. The weights of the sub-criteria can be seen in Figure 4 . In addition, Figure 4 showed that companies could get more detailed results about what kind of quality must be met by the supplier by knowing the sub-criteria weight. Material consistency occupies the top priority in the ceramic company. The company will automatically look for the supplier to provide the right material consistency than the supplier that offers suitable material suitability. As mentioned in the literature review, raw material consistency must be considered to produce quality products. Thus, material consistency concerning quality sub-criteria in selecting the supplier is needed.

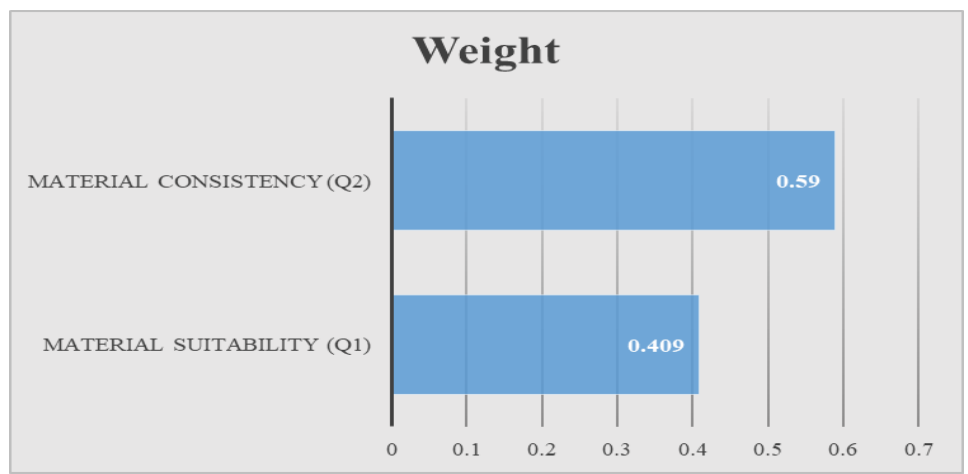

Figure 4. Summary of the weight of sub-criteria concerning the quality

After all, the weights of the criteria and sub-criteria are obtained. The analysis approaches the last question of which supplier is the best to answer this research's objective. The best supplier, 
according to the AHP method, can be seen in Figure 5 . Based on Figure 5, it can be seen that Semarang is the best feldspar supplier according to the AHP method. As a result, the company will choose Semarang to become the company's business partner compared to the other suppliers because Semarang has met the criteria that the company prioritizes the most. However, partners in the company are not dominated by only one supplier. In the next supplier selection stage, the unselected suppliers can improve their performance to win the supplier selection of other raw materials. The company also needs raw materials besides feldspar to produce ceramic tiles. This result is similar to the studies by (Pramita \& Wirawan, 2019; Wardhana \& Prastawa, 2018; Yuliani et al., 2017) resulted that quality occupies the top priority in selecting the supplier.

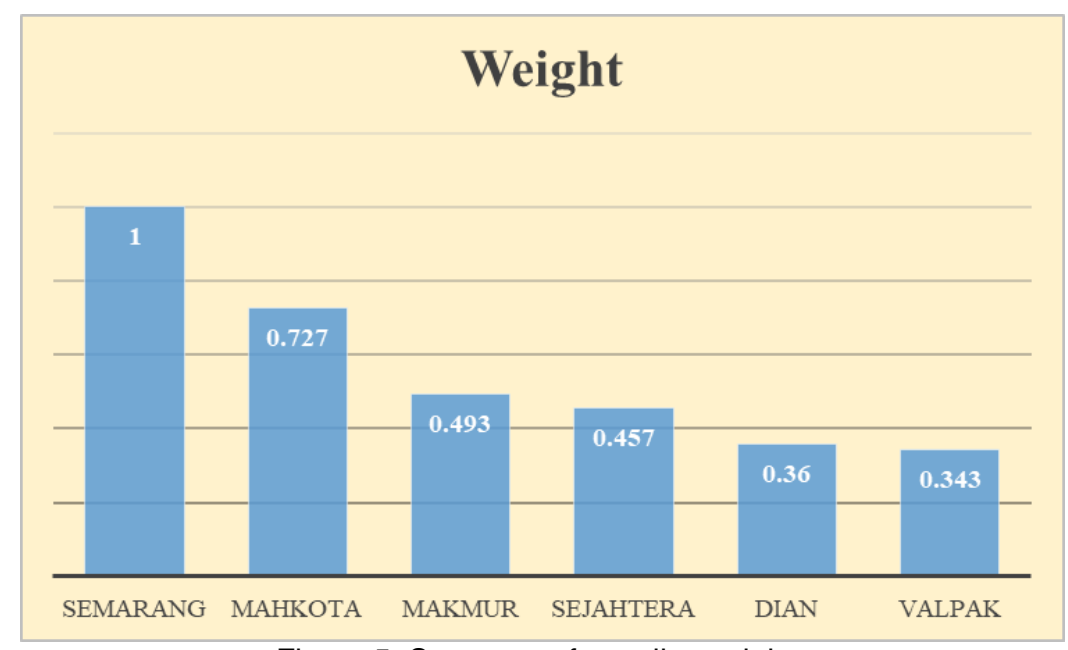

Figure 5. Summary of supplier weights

\section{Conclusions}

The objective of this study of selecting the best supplier has been reached using the AHP method best by evaluating the most important criteria needed by the company. It was found that supplier selection judged based on quality, cost, and delivery were insufficient. Thus, the QCDFR model consists of five criteria: quality, cost, delivery, flexibility, and responsiveness were more appropriate. Based on the results, criteria quality occupies the top priority with a total score of 0.456 . Thus, the company will automatically look for a supplier with good quality raw material. This result is similar to the studies by (Pramita \& Wirawan, 2019; Wardhana \& Prastawa, 2018; Yuliani et al., 2017) resulted that quality occupies the top priority in selecting the supplier. Thus, with this weight value, the company will automatically look for a supplier with the good quality compared to a supplier with good flexibility.

In addition, material consistency occupies the top priority in terms of quality sub-criteria with a total score of 0.590 . Thus, the company will automatically look for the supplier to provide the right material consistency than the supplier that offers suitable material suitability. Last, the supplier's rank was defined and found that Semarang is the best feldspar supplier with the most significant weight with a total score of 1 . Recommendation from this study, another method might be applied. For instance, Proposed by (Karimi et al., 2019) Analytical Network Process (ANP) is the recommended method to supplement the shortcomings of the AHP method because ANP is a highly capable and relevant approach in providing insight for strategic decisions in the ceramic and tile industries. 


\section{References}

Akmaludin, A., \& Suryanto, S. (2016). Pengambilan Keputusan Dalam Pemilihan Notebook Berbasis Teknologi dengan Metode Multycriteria Decision Making (MCDM). Bina Insani ICT Journal, 3(2), 329-340.

Alvira, R., \& Rusdah, R. (2020). Sistem Penunjang Keputusan Pemilihan Supplier Bahan Baku Kertas Dengan Metode QCDFR Dan Analytical Hierarchy Process: Studi Kasus Cv. Asaka Prima. IDEALIS: InDonEsiA Journal Information System, 3(1), 241-246.

Cengiz, A. E., Aytekin, O., Ozdemir, I., Kusan, H., \& Cabuk, A. (2017). A multi-criteria decision model for construction material supplier selection. Procedia Engineering 196, 294-301.

Didi, S. (2016). Supplier Performance Measurement of Organic Fertilizer with Analytical Hierarchy Process (AHP) Method in CV. ABC. Tekmapro: Journal of Industrial Engineering and Management, 11(1).

Dinna, T. R. (2019). Pemilihan Supplier Bahan Baku Material Kulit Di Industri Sepatu Dengan Metode Analytical Hierarchy Process (AHP). Universitas Mercu Buana, Jakarta.

Galińska, B., \& Bielecki, M. (2017). Multiple Criteria Evaluation of Suppliers in Company Operating in the Clothing Industry. Business Logistics in Modern Management, 17, 209-229.

Goli, A., \& Davoodi, S. M. R. (2018). Coordination policy for production and delivery scheduling in the closed loop supply chain. Production Engineering, 12(5), 621-631.

Haryanto, K. W., \& Sadeyah, S. A. (2018). Decision Support System for Raw Supplier Selection in a CV. Sinar Agung Perkasa Using Analytical Hierarchy Process (AHP) Method. SPIRIT Journal, 10(2), 1-8.

Karimi, M., Niknamfar, A. H., \& Niaki, S. T. A. (2019). An application of fuzzy-logic and greyrelational ANP-based SWOT in the ceramic and tile industry. Knowledge-Based Systems, 163, 581-594.

Kusaeri, A., Hermansyah, M., \& Bashori, H. (2016). Analisis Pemilihan Supplier Menggunakan Pendekatan Metode Analytical Hierarchy Process di PT. XX. JKIE. JKIE (Journal of Industrial Engineering Knowledge), 3(2), 51-61.

Li, C. C., Fun, Y. P., \& Hung, J. S. (1997). A new measure for supplier performance evaluation. IIE Transactions, 29(9), 753-758.

Navasiri, P., Kumar, V., Garza-Reyes, J. A., Lim, M. K., \& Kumari, A. (2016). How supplier selection criteria affect business performance? A study of the UK automotive sector. Proceedings of the 21st International Symposium on Logistics (ISL), 135-144.

Pirogo, B., \& Rumita, R. (2017). Application of Selection of Cast Iron Raw Material Supplier Part Handle Using Analytical Hierarchy Process Method (Case Study: CV Surya Cipta Inti Pratama, Semarang). Industrial Engineering Online Journal, 6(1). 
Pramita, N. U., \& Wirawan, A. (2019). Vendor Performance Evaluation Analysis Based on Vendor Performance Indicator (VPI) Criteria Using the Analytical Hierarchy Process (AHP) Method at PT. XYZ. JATI UNIK: Scientific Journal of Industrial Engineering and Management, 2(2), $108-117$.

Putra, F. E., Purba, H. H., \& Anggraeni, I. A. (2020). The optimization of distribution and transportation costs for common good products. International Journal of Industrial Optimization, 1(2), 111-120.

Rohimat, I. (2018). Analysis of Selection of Rice Supplier Using the Analytical Hierarchy Process Method. Jurnal Tiarsie, 14(1), 39-44.

Salimi, P. S., \& Edalatpnanah, S. A. (2020). Supplier Selection Using Fuzzy AHP Method and DNumbers. Journal of Fuzzy Extension \& Applications, 1(1), 1-14.

Siham, L., Jean-claude, B., Laurent, G., \& Zied, J. (2015). Designing Supply Chain Performance Measurement and Management Systems: A Systemic Perspective. 4th IEEE International Conference on Advanced Logistics and Transport (ICALT), 211-216.

Sinaga, T. S., \& Siregar, K. (2017). Supplier Selection based on the Performance by using PROMETHEE Method. IOP Conference Series: Materials Science and Engineering.

Sugiyono, M. (2017). Business Research Methods: Approach Quantitative, Qualitative, Combination, and R\&D. CV. Alfabeta.

Susilo, B. A., \& Mahdiana, D. (2020). Penerapan Metode Analytical Hierarchy Process (AHP) Dan Simple Additive Weighting (Saw) Dengan Model QCDFR Untuk Pemilihan Supplier Terbaik Pada UD. Bayu Agung Furniture. IDEALIS: InDonEsiA Journal Information System, 3(1), 7884.

Viarani, S. O., \& Zadry, H. R. (2015). Analysis of Supplier Selection using Analytical Hierarchy Process Method at PT Semen Padang's Indarung VI Project. Journal of Industrial Systems Optimization, 14(1), 55-70.

Wardhana, D. A. K., \& Prastawa, H. (2018). Analysis of Supplier Selection Using Analytical Hierarchy Process Method (Case Study: MSME Diana Bakery). Industrial Engineering Online Journal, 6(4).

Winarso, W., Syarif, F., \& Untari, D. T. (2021). Supplier Selection Of 40th Container in PT Tribudhi Pelita Indonesia Using Analytical Hierarchy Process (AHP) Method. Academy of Strategic Management Journal, 20, 1-6.

Yuliani, E. N. S., Kholil, M., \& Safitri, S. (2017). Selection of Alternative Suppliers Using a Vendor Performance Indicator (VPI) Approach and Analytical Hierarchy Process (AHP) Methods at PT. Sumber Berkat Anugerah Indonesia. Seminar Nasional Teknik Industri [SNTI2017]. 
This page is intentionally left blank. 